prehensive lists given at the end of Part 1 , of plants which can be raised from seed, and the classified alphabetical lists of plants, with information about the suitable vegetative method of increase of each, are most useful.

The chapter on the propagation of ferns is very welcome, for published information on this subject is very scattered. It is unfortunate that the author has used an invalid botanical name for the male fern, and has described the compound pinnate frond of Wooduardia radicans as long and entire and "not dissimilar from that of our native harts-tongue". However, a few errors are inevitable in a book of this size, which as the author states "is intended to combine something of everything in a small compass without loss of standard", and the number of inaccuracies is remarkably small.

The somewhat unusual arrangement of the text in numbered paragraphs is excellent for precise reference, and the entries in the very full index are based on these numbers. This little book should prove a veritable vade-mecum to the amateur gardener and to many of the smaller commercial growers. Botanists and teachers of the science and practice of horticulture will also find in it much of interest.

\section{SEAWEED UTILIZATION}

\section{Seaweeds and their Uses}

By Prof. V. J. Chapman. Pp. xiv $+287+20$ plates. (London: Methuen and Co., Ltd., 1950.) 25s. net.

TN this work Prof. V. J. Chapman has attempted $I$ to bring the available information into the com. pass of a single volume, to make it acceptable to the general reader and sufficiently comprehensive to be of value to the specialist. The task was obviously difficult, and he is to be congratulated on the amount of information that he has made available.

The author's preface is perhaps unnecessarily doleful, as indeed his subsequent chapters show, and some of the statements he makes in the preface are of so sweeping a character that one hesitates to accept them without further consideration. For example, on p. ix he writes: "The spread of civil. isation with its greater range of foods is slowly eliminating the use of seaweeds as human foods, even in such strongholds as Japan and Hawaii. One must therefore accept the fact that the present known types of edible algæe will never again achieve a wide use." According to the report of $\mathbf{E}$. J. Ferguson Wood on the uses of seaweeds in Japan, soon after the close of the Second World War, the addition of brown seaweeds to the flour was obligatory in many prefectures, and there appears to be every indication that the Japanese seaweed industry is rapidly recovering. Many seaweeds have a high protein and carbohydrate content and are therefore a potential source of food, if it could be converted into a form that is readily assimilable by humans. With the present numerical state of the world's population, when further sources of food are urgently needed, one wonders whether the second sentence in the quotation is not a pre-judgment of what may become an important issue.

The book contains nine chapters, which deal successively with the occurrence and distribution of seaweeds, with historical aspects of seaweed utilization and with accounts of different industries which have assumed importance from time to time. The last chapter discusses the location of the world supplies and the methods of harvesting.

War-time difficulties have hampered Prof. Chapman in the publication of the book, and an addendum summarizes some of the more recent work. The inclusion of an extensive bibliography greatly enhances the value of the book.

There are fifty-two illustrations in the text, some of which appear to lack just the right mode of delineation of the plant. For example, the inclusion of the characteristic fruiting pustules would have made the drawings of Chondrus crispus on p. 11 much more convincing. The relative size of Fucus serratus and Himanthalia lorea on p. 7 is misleading to the uninitiated, and it seems a pity that the picture of Fucus vesiculosus on p. 5, so profuse in its bladders, should lack receptacles. The twenty plates at the end of the volume depict various aspects of seaweed harvest and manufacture and are of considerable interest.

LILY NFWTON

\section{THRIFT BOOKS}

Evolution in Outline

By Prof. T. Neville George. (Thrift Books, No. I.) Pp. 126. (London: Watts and Co., Ltd., 1951.) 1s. net.

What's all this about Genetics ?

By Rona Hurst. (Thrift Books, No. 3.) Pp. 124. (London: Watts and Co., Ltd., 1951.) 1s, net.

The Ladder of Life from Molecule to Mind

By A. Gowans Whyte. (Thrift Books, No. 4.) Pp. 120. (London: Watts and Co., Ltd., 1951.) 1s, net. THE continuing success of the 'Thinkers' Library series over the past twenty-two years has impelled its publishers to launch a companion series called Thrift Books. Four of these have now been published, one dealing with theatre-going and the three under review with biological topics. Each is a new book specially written for the series and, in these times, the series offers remarkable value for money.

"Evolution in Outline" is a concise account of organic evolution by an acknowledged expert who examines the merits and deficiencies of various theories. Whether the closely knit and sparsely illustrated text will be popular with the general reader, whose taste has been accustomed to the lavishly produced periodicals and books on biological topies which have so freely appeared in recent years, is open to question.

Mrs. Hurst's book, on the other hand, will present little difficulty to the 'ordinary reader' for whom it is intended; the inclusion of relevant biographical details about famous investigators illuminates her account of important discoveries in genetics and quickly captures interest.

Gowans Whyte in his book describes the development of mind through the biological ages. His skilful selection from the writings of leading authorities in neurology and psychology are carefully interpolated to support his argument and win the attention of the reader; this he succeeds in doing.

If the standard of these three books is maintained in later volumes of the series, the publishers of Thrift Books may be content that they have not only increased the range of scientific knowledge but also extended the rational attitude of scientific investigators among the general public.

T. H. HaWkINS 